\title{
The History of the Basal Ganglia: The Contribution of Karl Friedrich Burdach
}

\author{
André Parent \\ Département de Psychiatrie et de Neurosciences, Faculté de Medicine, Université Laval, Québec, Canada. \\ Email: Andre.Parent@fmed.ulaval.ca
}

Received October $23^{\text {rd }}, 2012$; revised November $22^{\text {nd }}, 2012$; accepted November $30^{\text {th }}, 2012$

\begin{abstract}
It took many centuries for the basal ganglia (BG) to be recognized as specific brain entities involved in the control of psychomotor behavior. Andreas Vesalius (1514-1564) was the first to delineate this set of structures, but he did not name them nor payany attention to their functional significance. This was left to the English physician Thomas Willis (1621-1675), who used the term corpus striatum (striated or chamfered body) to designate the largest BG constituent, which he considered a major sensorimotor integration center. Willis's pioneering description influenced markedly some 18th and 19th centuries scholars, particularly the German physician and anatomist Karl Friedrich Burdach (1776-1847). Burdach's insightful studies of the human brain are summarized in a three-volume treatise entitled Vom Baue und Leben des Gehirns (1819-1826). This landmark opus provides a description of the BGwhose originality has largely been overlooked. Burdach's careful investigation allowed him to differentiate the caudate nucleus from the putamen, which he respectively termed Streifenhügel (elongated hillock) and Schale (shell). He also called the putamen Linsenkern (lens-shaped nucleus), a term that he admittedly borrowed from his compatriot Johann Christian Reil (1759-1813). He further identified a paler structure (blasser Klumpen) within the inner portion of the lentiform nucleus that he called globus pallidus, and correctly identified its inner and outer segments (innern und äussern Theil). He aptly pointed out that the major BG nuclei are separated from one another by fibers fascicles that he termed inner and äussre Capsel (internal and external capsules). Burdach also referred to the substantia nigra (schwarzgraue Schicht or stratum nigrum) and claustrum (Vormauer), but gave full credit to the French anatomist Félix Vicq-d'Azyr (1748-1794) for their discovery. Although Burdach did not comment much on BG function, his anatomical description was sufficiently cogent to be still in use two centuries after its inception.
\end{abstract}

Keywords: Basal Ganglia; Movement Disorders; Striatum; Globus Pallidus; Putamen; Neuroscience History

\section{Introduction}

The basal ganglia are a large, interconnected set of subcortical hemispheric structures that plays a crucial role in the control of movement, as exemplified by the motor disturbances that occur when these nuclei are pathologically affected, such as in Parkinson's disease or Huntington's chorea [1]. Historically, the presence of large structures at the basis in the brain was already noted in the Antiquity, but the basal ganglia per se were not fully recognized until the 19th century. Here, we review the history of the lengthy emergence of the basal ganglia concept, with a particular attention to the key role that the German neuroanatomist Karl Friedrich Burdach played in the discovery and naming of the different basal ganglia components.

\section{A Short Biography}

Karl Friedrich Burdach (Figure 1) was born in Leipzig

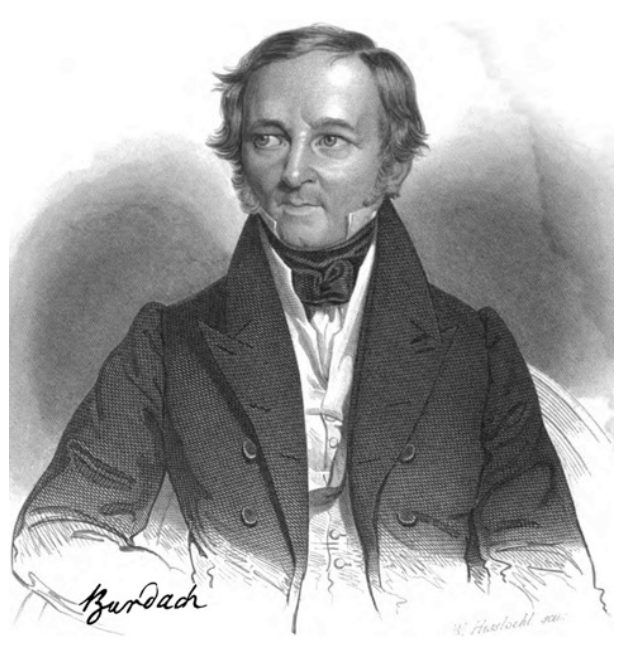

Figure 1. A portrait of Karl Friedrich Burdach at 56 years old by the Viennese painter and lithographer Joseph Kriehuben (1800-1876). It served as a frontispiece for Burdach's Anthropologiefür das gebildetePublicum published in 1847 [2]. 
on June 12, 1776. Son and grandson of physicians, he studied medicine in his native town, but had to move to Vienna to acquire the clinical expertise necessary to initiate his medical practice. After obtaining a medical doctor degree from Leipzig University in 1799, he started practicing and lecturing in Leipzig, on a private basis, while looking for an official university appointment. During this period Burdach became fascinated by the ideas of Friedrich Wilhelm Joseph von Schelling (17751854), who was the leader of the Nature Philosophy (Naturphilosophen)'s group that occupieda crucial position in the intellectual life in Germany at that time. By attempting to understand particular aspects of the natural world as integral parts of a coherent whole, Burdach himself progressively became a prominent scientific figure of the Nature Philosophers. In 1811, Burdach obtained a position as professor of anatomy, physiology, and forensic medicine at the University of Dorpat in Tartu, Estonia, where he began intensive studies of the anatomical and developmental aspects of the human and animal brains. Three years later he was back in Germany occupying the chair of anatomy and physiology at Konigsberg. In collaboration with the embryologists Martin Heinrich Rathke (1793-1860) and Karl Ernst von Baer (1792-1876), he created the Konigsberg's Anatomical Institute (Königliche Anatomische Anstalt), which he headed from 1817 until 1827, later restricting himself to teaching and research activities. After a very active life as a scientist mostly devoted to the study of embryology, history of sciences, and the anatomy and physiology of the brain, as well as a prolific writer who tackled a wide variety of subjects, Burdach died in Konigsberg on July $16,1847$.

\section{A Masterpiece in Neuroanatomy}

The results of Burdach's intensive work on the developmental, anatomical and historical aspects of the human brain are cogently summarized in a three-volume treatise entitled Vom Baue und Leben des Gehirns (Of Structure and Life of the Brain) [3], published between 1819 and 1826, and which Burdach himself considered as his masterpiece in neuroanatomy. The first two volumes, which appeared in 1819 and 1822, respectively, deal essentially with the anatomy of the brain, whereas the third volume that appeared in 1926 is entirely devoted to the function of the brain. This work is one of the best examples of the approach taken by the Romantic physiologists: while attempting to be as comprehensive and systematic as possible, Burdach sought to show that the nervous system was itself a unity and not just a conglomerate of various anatomical structures. Burdach had an obvious gift for naming concrete structures as well as more sophisticated concepts. For example, Burdach coined the term "morphology" independently of Johann Wolfgang von Goethe (1749-1832), and he was also the first to use the word "biology"; both terms appeared in his first physiology text, which was published in 1800 [4]. Furthermore, Burdach's Vom Baue und Leben des Gehirnscontains a multitude of new names for various nuclei and fiber systemsof the central nervous system, including the pulvinar, amygdaloid complex, red nucleus, lamina terminalis, pallium, cingulum, longitudinal association tracts, subiculum, alveus, cuneus, precuneus, and the fasciculus cuneatus to which his name is still attached. Of course, Burdach did not discover all the structures he named, but he nevertheless provided the first description and illustration of many of them.

As a genuine Nature Philosopher, Burdach attributed much importance to the historical aspect of the advancement of knowledge. Hence, throughout his neuroanatomy treatise he gives an honest credit to most of his predecessors in the field of neuroanatomy. Furthermore, a large section (from page 189 to 400) of the second volume of Vom Baue und Leben des Gehirns, titled Anmerkungen (comments) provides ahistorical review of brain anatomy that surpasses the earlier works of the French physician and anatomist Antoine Portal (17421832) [5] and the Swiss physiologist Albrecht von Haller (1708-1777) [6]. A close look at this section will allow us to briefly review the history of the basal ganglia, that is, the way these structures were discovered, named, and integrated into the current framework of our thinking about brain function.

\section{Anmerkungen}

The presence of prominent structures lying at the basis of the cerebral hemisphere was probably known since the Antiquity. In the Anmerkungen's section of Vom Baue und Leben des Gehirns, Burdach recalls that, as early as the second century, Claudius Galenus (Galen, 129-201) noted the presence of these basal forebrain structures, which he referred to as glutia (glutia, buttocks). However, we had to wait more than thirteen centuriesbefore a first crude delineation of the basal ganglia appeared in the literature, thanks to the work of the famous Flemish anatomist Andreas Vesalius (1514-1564), who published his landmark treatise De Humani CorporisFabrica in 1543 [7]. In the seventh book of this treatise, one finds a figure that provides a surprisingly detailed outline of the various basal ganglia components (Figure 2). Unfortunately, neither in the legend to this figure, which we probably own to the Flemish artist Jan van Calcar (c. 1499-1545), nor elsewhere in the text did Vesalius name these structures nor comment upon their possible function.

One of Burdach's “Immortals” was Thomas Willis (1621-1675) of Oxford. Willis applied a new, blunt dissection method that allowed him to discover a structure 


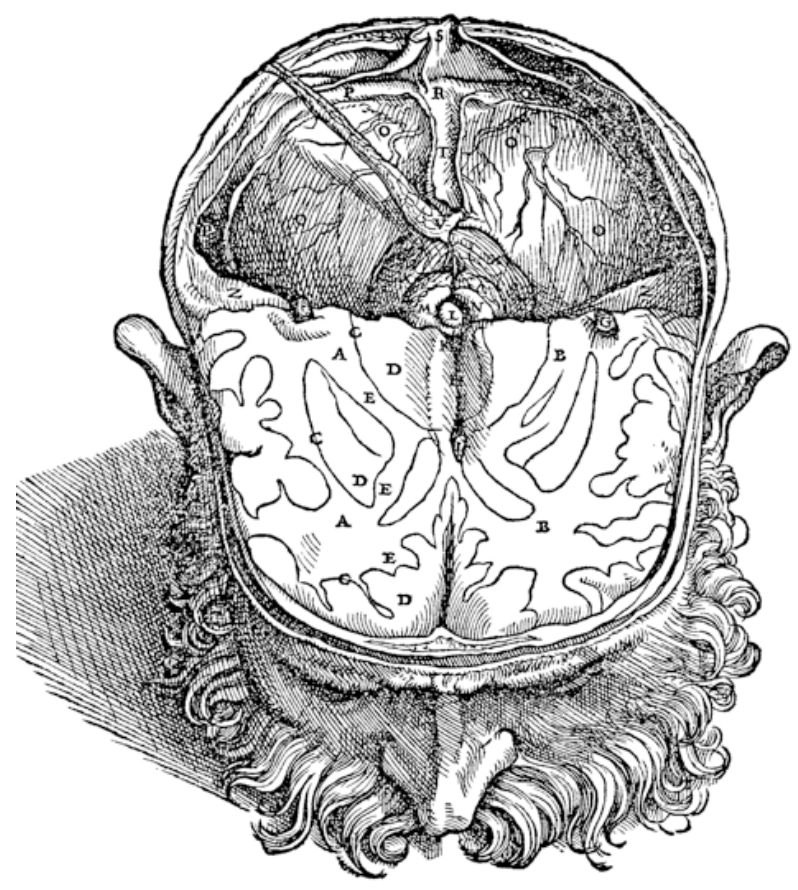

Figure 2. Andreas Vesalius's depiction of the basal ganglia. This reproduction of plate VII of book VII of Vesalius' Fabrica [7] shows a horizontal section though the human brain. The rendition of the anterior portion of the right (A) and left (B) hemisphere displayed a rather accurate view of the basal ganglia, particularly on the right side. Bundles of white matter (identified by the letter $E$ ), corresponding roughly to our internal capsule, are shown separating masses of grey matter (identified by the letter $D$ ), the lower medial one corresponding to the thalamus and the upper lateral one to the putamen. The caudate nucleus is also clearly outlined as a structure separated from the putamen by white matter. Also note, on the right side, the unmarked line separating the putamen from the globuspallidus.

displaying a typical grey and white matter striation at the apex of the brainstem and which he called corpus striatum. In his celebrated brain anatomy treatise (Cerebri anatome, 1664) Willis provides a detailed description of the striatum, which the author summarizes as follows: "Corpus striatum sive medullae oblongatae apices sunt duo prominentiae lentiformes" (The corpus striatum lies at the apex of the brainstem, where it stands as two lenslike prominences) [8]. The great artistic talent of Christopher Wren (1632-1723) was also exploited by Willis to vividly illustrate the corpus striatum in Cerebri anatome (Figure 3). Willis attributed to the corpus striatum a crucial role in the control of motor behavior, a function that was to remain closely attached to the basal ganglia until the end of the 19th century, at which time the involvement of the cerebral cortex in the initiation of volontary movement began to be understood. In addition to their mutual dedication to brain anatomy, Burdach's admiration for Willis stems from the fact that they both shared a similar attitude towards the way natural science should

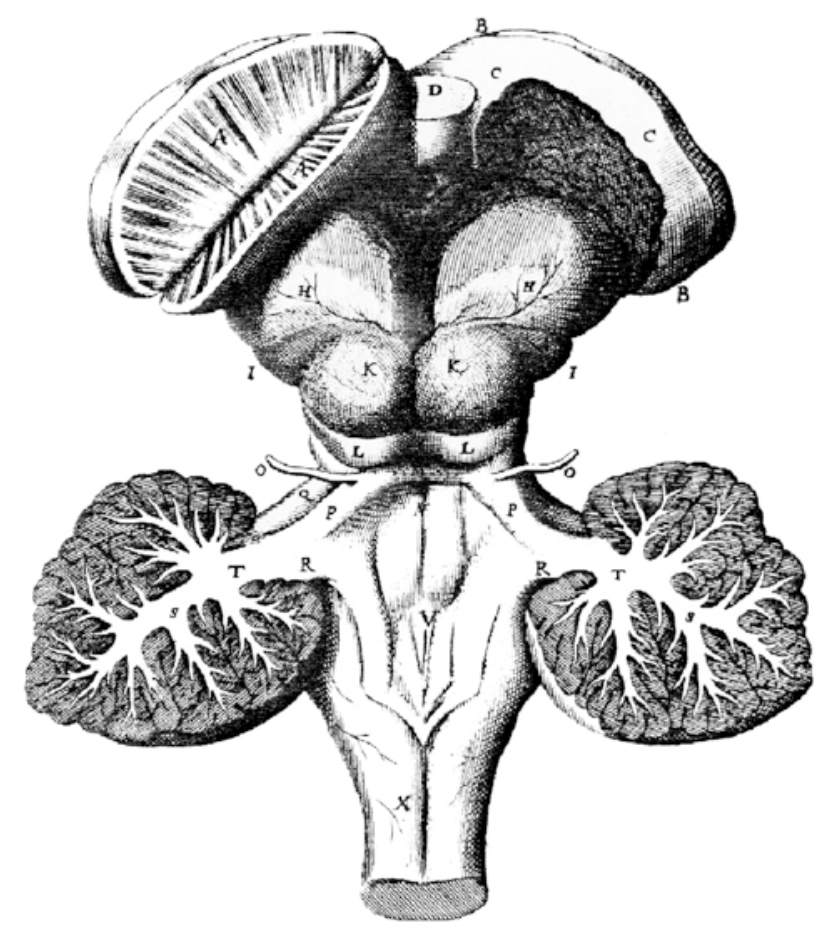

Figure 3. Thomas Willis's view of the basal ganglia. A reproduction of plate VIII from Willis' Cerebri anatome [8] that shows a dorsal view of the brainstem and basal ganglia in a sheep. The hemispheres have been removed to better illustrate the basal ganglia, and the corpus striatum on the right side has been cut in half to show its characteristic striations.

be approached. Raymond Vieussens (1641-1715) of Montpellier was one of the firsts to refer to the basal ganglia as the "great cerebral ganglion." In his Neurographia universalis of 1684 [9], he subdivided this large structure into six different sectors, the anterior one corresponding to Willis' corpus striatum and the posterior one to the thalamus. More than a century later, the French anatomist Félix Vicq d'Azyr (1748-1794), who was also Queen Marie-Antoinette's private physician, discovered the substantia nigra (locus niger crurum cerebri) and provided pictures of the basal ganglia of a quality never exceeded before. His famous Traité d'anatomie et de physiologie (1786) [10] contains several plates in which the various components of the basal ganglia, including caudate nucleus, putamen and globus pallidus, are clearly delineated form one another (Figure 4). Unfortunately, somewhat like Vesalius before him, Vicq d'Azyr did not identified these structures individually, focusing more on the fiber fascicles (that he called arcades) separating the nuclei.

Burdach also reminds us that, at the beginning of the 19th century, both Johann Christian Reil (1759-1813) in Germany and Franz Joseph Gall (1758-1828) in France made important contributions to the anatomy of the brain in general and of the basal ganglia in particular $[11,12]$. 


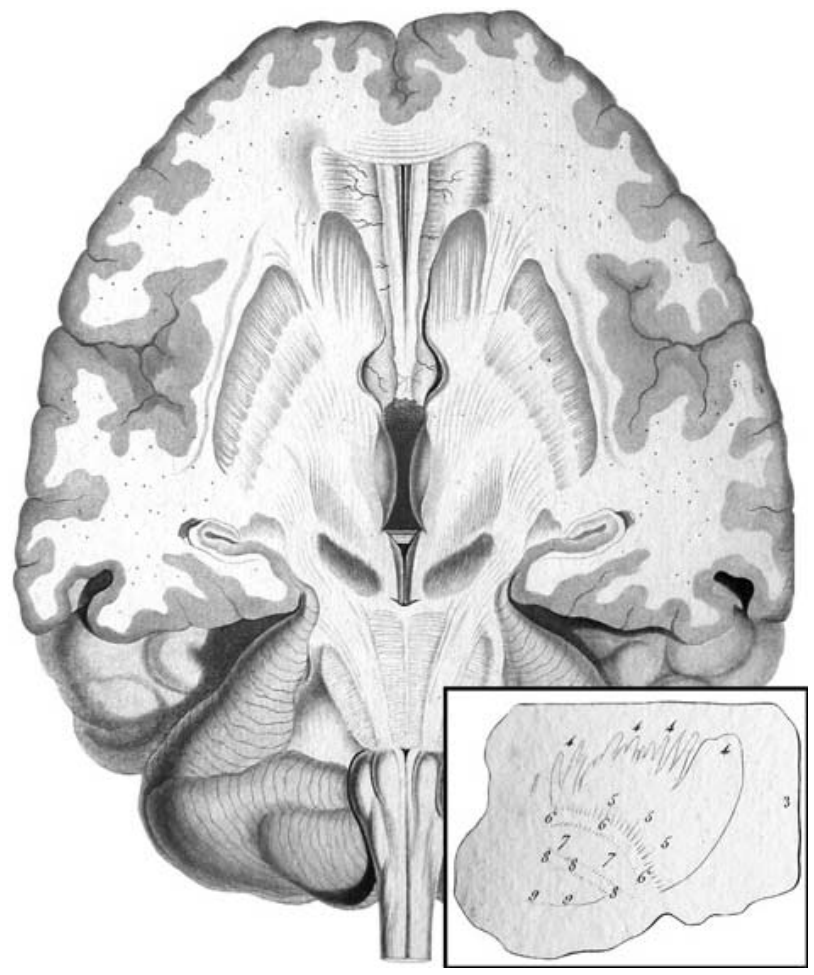

Figure 4. Félix Vicq d'Azyr's representation of the basal ganglia. A reproduction of plate XXII from Vicq d'Azyr's Traité d'anatomie et de physiologie [10] that depicts a horizontal section of the human brain passing though the basal ganglia anteriorly and the substantia nigra posteriorly. The caudate nucleus, putamen and globus pallidus separated from one another by groups of nerve fibers are clearly singled out in this drawing, but not specifically named by the author. The claustrum and the substantia nigra (locus niger crurum cerebri) are also depicted in this beautiful illustration that was drawn and engraved by Alexandre Briceau and originally printed in color. The insert at the bottom is a drawing taken from palate XIV of Vicq d'Azyr's treatise showing a sagittal view of the human basal ganglia, with the putamen and the inner and outer pallidal segments separated by fiber fascicles (arcades), which correspond to our internal (labeled 8) and external (labeled 6) medullary laminae.

Gall referred to the basal ganglia as le grand ganglion cérébral (the great cerebral ganglion) with a superior and an inferior part corresponding respectively to Willis' corpus striatum and thalamus (couche optique). In the treatise Anatomie et physiologie du système nerveux, which he published in 1810 in collaboration with Johann Kaspar Spurzheim (1766-1832) [11], Gall provided astonishingly accurate illustrations of the basal ganglia, with an outer an inner portion of the corps strié corresponding to our caudate nucleus and putamen, respectively (Figure 5). As for Johann Christian Reil, in addition to the epithet ganglion (Greek for swelling), he was among the firsts to use the term Kern (German for core or kernel that became nucleus in Latin) to designate masses of gray

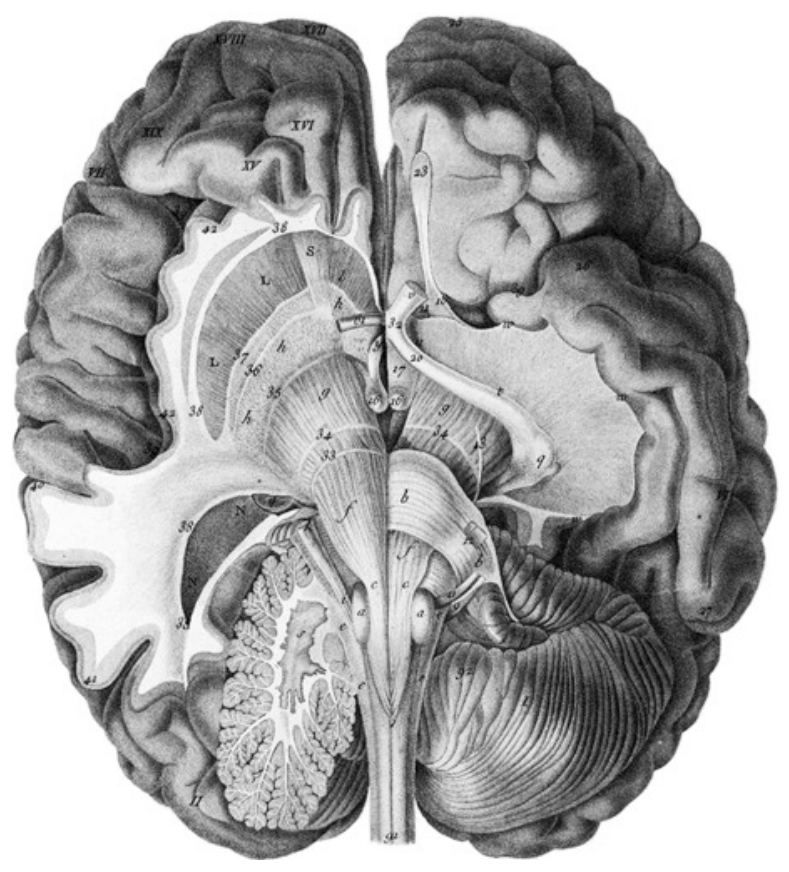

Figure 5. Franz Joseph Gall depiction of the basal ganglia. This reproduction of plate V from Gall and Spurzheim's Anatomie et physiologie du système nerveux [11] displays a horizontal section of the human brain prepared according to Gall's method of dissection, which allowed to follow the trajectory of the main ascending and descending fiber systems. Gall subdivided his grand ganglion cerebral into a superior and an inferior part associated with the corps strié and the couche thalamique, respectively. In this drawing, the grand ganglion cérébral supérieur is further subdivided into an outer (L) and inner (l) portion, corresponding respectively to our putamen and caudate nucleus, by a group of nerve fibers corresponding to the anterior limb of our internal capsule. The globus pallidus, with its two segments, is also recognizable (h), together with the claustrum, but the authors do not comment specifically upon these structures.

matter located inside the brain. Reil also frequently employed the word Hügel (German for hillock or monticule) for the same purpose as, for example, in Vierhügel (superior colliculus) and Sehhügel (thalamus). In regards to the basal ganglia, Reil noted the presence of a Capseln (fiber capsule) around the great cerebral ganglion, whose external surface, he remarked, had the shape of a Linse (lens or lentil) [12]. However, Burdach reminds us that the lens-like aspect of the external portion of the corpus striatum had previously been notedby Willis, who used the term prominentiae lentiformes to describe the macroscopic aspect of the corpus striatum.

\section{A Seminal Contribution to Basal Ganglia Anatomy}

In Vom Baue und Leben des Gehirns, Burdach provided a description of the basal ganglia whose originality has been largely overlooked. In this landmark opus, Burdach 
referred to this set of subcortical structures as the anterior portion of the Hirnstammganglien (brainstem ganglion). After careful examinations of frontal and parasagittal human brain sections, he was able, for the first time, to clearly differentiate the caudate nucleus from the putamen (Figures 6 and 7). He used the word Streifenhügel (elongated hillock) to designate the caudate nucleus, but gave credit to Vincenzo Malacarne (1744-1816) for having been the first to mention the existence of such an elongated mass of grey substance in the brain, but Malacarne himself might have picked-up this observation from a translation of Galen's work provided by Avicenna (c. 980-1037) early in the Middle Ages [5]. Burdach also gave a very detailed description of our lentiform nucleus, which he named Linsenkern (lens-shaped nucleus), a

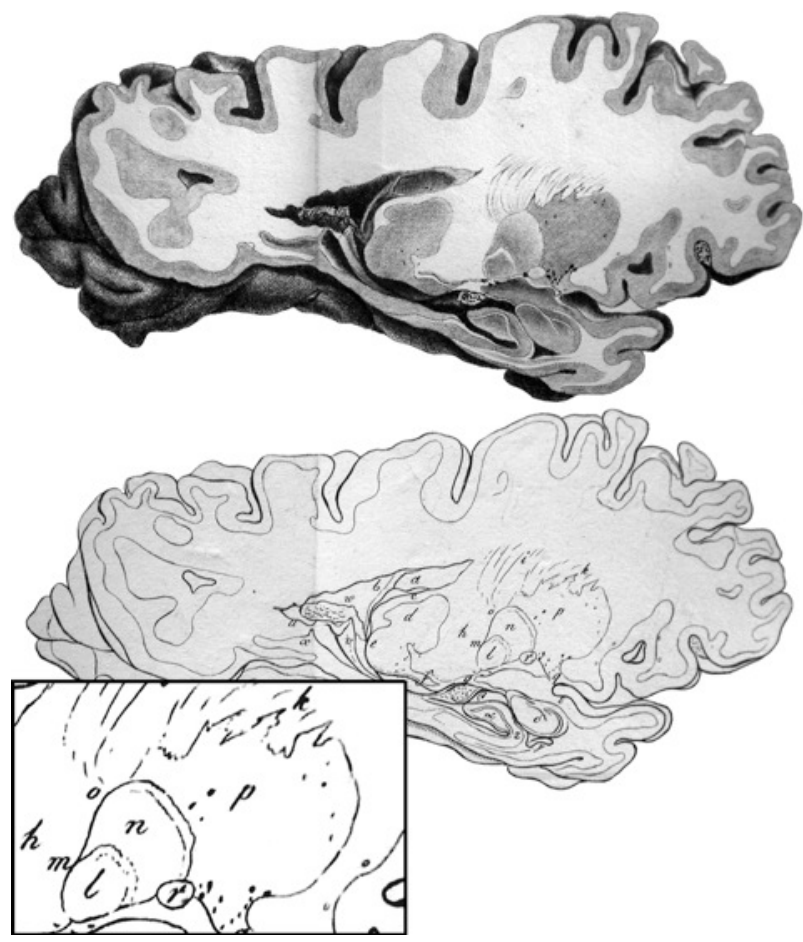

Figure 6. Karl Friedrich Burdach's representation of the basal ganglia. This reproduction of plate IX, book II, of Burdach's Von Baue und Leben des Gehirns [3] shows a parasagittal slice of the left hemisphere of a human brain, cut one inch from the midline, but somewhat collapsed in fixation. The various components of the basal ganglia are here defined clearly for the first time and their location is indicated by letters in the line drawing of the lower panel, a part of which has been enlarged (insert at the bottom) to better appreciate the details. The letters $a$ and $b$, for example, point to the tail of the caudate nucleus; $d$ to thalamus; $h$ to internal capsule; $l-q$ to lenticular nucleus. Burdach's distinction between the different components of the human lenticular nucleus is better appreciated in the insert, with the putamen (p) clearly differentiated from the medial (l) and lateral (n) segments of the globus pallidus by groups of fiber bundles that are collectively termed begränzende Markblat (bordering white matter).

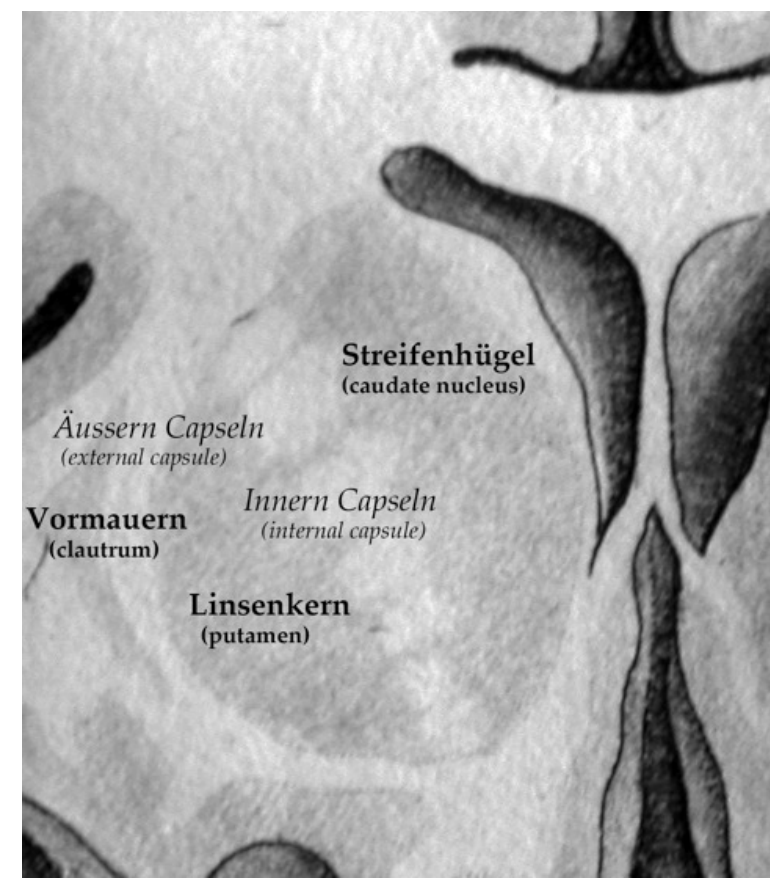

Figure 7. A reproduction of the upper part of plate III, book II, of Burdach's Von Baum und Leben des Gehirns [3] showing a coronal view of the right hemisphere of a human brain. This drawing provides a first detailed view of the basal ganglia, as they appear at precommissural level. The Streifenhügel (caudate nucleus) is clearly separated from the Linsenkern (lenticular nucleus, consisting at this rostral level only of its Schale or envelope that Burdach called putamen) by the fiber of the innern Capseln (internal capsule). The Vormauer (claustrum) is also well delineated, with the äussern Capseln (external capsule) separating it from the Linsenkern (lentiform nucleus). Burdach's original designations (together with their present-day correspon-dences) have been added to J. F. Schröter's original engraving to facilitate the structure identification.

term that he admittedly borrowed from his compatriot Reil, who himself borrowed it from Willis. He also recognized that his Linsenkern was not topographically and cytologically a monolithic entity. His called his more grayish lateral part Schale (shell, peel) or putamen. He further identified a paler structure (blasser Klumpen) within the inner portion of his Linsenkern that he called globus pallidus, and correctly identified its inner and outer segments (innern und äussern Theil). He aptly pointed out that the major basal ganglia nuclei were separated from one another by fibers fascicles that he termed inner Capseln and äussre Capseln, which correspond to our internal and external capsules, respectively. Burdach also referred to the substantia nigra (schwarzgraue Schicht or stratum nigrum) and claustrum (Vormauer, a bulwark), which are clearly visible in some of the plates that illustrate his findings (Figures 6 and 7), but he gave full credit to Vicq-d'Azyr for their discovery. The subthalamic nucleus was perhaps the only basal ganglia 
component that escaped Burdach's scrutiny. The nucleus was discovered in 1865 by the French alienist Jules Bernard Luys (1828-1897) [13,14], butits role as one of the main driving forces of the basal ganglia has been fully appre- ciated only at the end of the 20th century [1,14].

\section{A Nature Philosopher's View of Basal Ganglia Function}

Burdach's physiological considerations on the basal ganglia are those of a typical Naturphilosophen indulged in speculation on the discrete localization of functions in specific brain areas. He believed that the basal ganglia were the site of sensory perception and consciousness. Volition, he thought, emerges from the corpus striatum, whereas sensation, particularly visual, and consciousness originate from the thalamus. However, he had no firm experimental observations to support any of these affirmations, and he did not even feel the need to search for such evidence. At the end of his career, Burdach's speculations were out of the realm of the vigorous neuroscience research that was going on at that time. For example, he did not take seriously into account the results that were emerging from the use of the microscope, including the cell theory. His last account of the nervous system was more concerned with nerve fibers than with that of nerve cells, which he designated by using old and unspecific terms such as Körnchen (granules) and Kugeln (globules). Despite these weaknesses regarding the physiological part of his work, Burdach deserves our entire recognition for having provided us with an anatomical description of the basal ganglia that was sufficiently cogent to be still in use two centuries after its inception.

\section{REFERENCES}

[1] A. Parent and L.-N. Hazrati, "Functional Anatomy of the
Basal Ganglia. I. The Cortico-Basal Ganglia-ThalamoCortical Loop. II,” Brain Research Review, Vol. 20, No. 1, 1995, pp. 91-154. doi:10.1016/0165-0173(94)00007-C

[2] K. F. Burdach, "Anthropologiefür das GebildetePublicum,” Balz, Stuttgart, 1847.

[3] K. F. Burdach, "Vom Baue und Leben des Gehirns und Rückenmarks,” Vol. 3, Dyk, Leipzig, 1819-1826.

[4] K. F. Burdach, "Physiologie,” Weidmann, Leipzig, 1810.

[5] A. Portal, "Histoire de l'Anatomie et de la Chirurgie," Vol. 7, Didot, Paris, 1770-1773.

[6] A. von Haller, "Elementa Physiologiae Corporis Humani,” Vol. 8, Bousquet, Lausanne, 1757-1766.

[7] A. Vesalius, "De Humani Corporis Fabrica Libri Septem,” J. Oporinus, Basel, 1543.

[8] T. Willis, "Cerebri Anatome Cui Accessit Nervorum Descriptio et Usus," Flesher, Martyn and Allestry, London, 1664.

[9] R. Vieussens, “Neurographia Universalis,” Certe, Lyon, 1684.

[10] F. Vicq d’Azyr, “Traité d’Anatomie et de Physiologie,” Didot, Paris, 1786.

[11] F. J. Gall and J. K. Spurzheim, “Anatomie et Physiologie du Système Nerveux en Général et du Cerveau en Particulier," Schoell, Paris, 1810.

[12] J. C. Reil, “Das Verlängerte Rückenmark, die Hinteren, Seitlichen und Vorderen Schenkel des Kleinen Gehirns und die Theils Strangförmig, Theils als Ganglienkette in der Axe des Rückenmarks und des Gehirns fortlaufende graue Substanzv, Archiv für die Physiologie (Halle), Vol. 9, 1809, pp. 485-524.

[13] J. B. Luys, "Recherches Sur le Système Nerveux Cérébro-Spinal, Sa Structure, Ses Fonctions et Ses Maladies,” Baillière, Paris, 1865.

[14] A. Parent, "Jules Bernard Luys and the Subthalamic Nucleus,” Movement Disorders, Vol. 17, No. 1, 2002, pp. 181-185. doi:10.1002/mds.1251 